東洋大学学術情報リポジトリ Toyo University Repository for Academic Resources

For eword to the Engl i sh Transl at i on

\begin{tabular}{|l|l|}
\hline 著者 & Set suo M ur a \\
\hline 圂名 & The Educat i onal Pri nci pl es of Enryo I noue \\
\hline 開始ページ & 10 \\
\hline 終了ページ & 13 \\
\hline 出版年月日 & 2015 \\
\hline URL & ht t p: //i d. ni i . ac.j p/1060/00011901/ \\
\hline
\end{tabular}




\title{
Foreword to the English Translation
}

\author{
By Setsuo Miura
}

Inoue Enryo Memorial Academic Center

Professor of the Faculty of Life Design

August 2011

The original edition of this book was published in 1987 to commemorate the 100th anniversary of Toyo University. In 1978, ten years before the 100th Anniversary of Toyo University, The Research Association of Enryo Inoue started with three groups for the study of Dr. Inoue, the founder of Toyo University, and his achievements. The third group was formed with researchers in philosophy and social science, including myself. Its purpose was to view Dr. Inoue within the context of the modern history of Japan, and make new objective research based on recently collected materials.

When the third group had studied for five years, and was looking for the next research step, Prof. Iijima, a member from the Department of Philosophy, reported The Educational Principles of Enryo Inoue. Hiroo Takagi, chief of the group and a professor of the Faculty of Sociology, highly praised his report, and proposed to make the Educational Principles of Enryo Inoue the comprehensive theme of the third group.

With unanimous approval from the research members, the third group started its comprehensive study based on each individual member's research, 
a process which continued for three years. The third group through its ten-year research achieved much in basic understanding, leading to a comprehensive picture of Enryo Inoue. As a result, a new image of Dr. Enryo Inoue emerged.

Meanwhile, Toyo University was active in its 100th Anniversary commemorative projects. The Memorial Publication Committee originally planned to publish a collection of Dr. Inoue's impressive words in a more accessible style, and this suggestion was accepted.

As a result, Professor Takagi became the project supervisor, and I was selected as the writer of the book. However, this abrupt change of plan caused great difficulties.

In the very year of the 100th Anniversary, Professor Takagi (a member of the publication committee) proposed that the university publish the life of Enryo Inoue and his educational principles as a pocket book entitled The Educational Principles of Enryo Inoue. Although there were already research results made through the comprehensive studies of the third group, they were essentially academic research products. We could not use these materials directly for writing this book. It took time to put the research results into a book that could be easily understood by general readers.

In a short period of approximately six months, overcoming various barriers, Professor Takagi and I worked hard and finally could produce the first version of this book The Educational Principles of Enryo 
Inoue just before the Anniversary Day of Toyo University on November 23.

This book was designed on the one hand to comprise the educational philosophy of Enryo Inoue and the history of Toyo University while on the other hand adding his biography and thoughts. Perhaps as a consequence, after the publication of the first edition, there arose a movement within the university to look for a new educational principle for the university which would start with recognition of the origin of the foundation of the university from a fresh perspective. It was a symbol of this movement that the Inoue Enryo Memorial Academic Center was soon organized and has been managed directly by the university board. Since then, this book has been revised upon the request of the university, then published and distributed throughout the university.

By Atsuo Miyauchi

Professor of the Faculty of Life Sciences

May 2011

Years ago when I was one of the researchers at the Inoue Enryo Memorial Academic Center (20035), I translated most parts of this book into English. Last year I proposed the publication of an English version of this book for the 125th Anniversary of Toyo University in 2012. Soon after my proposal was accepted by President Makio Takemura and 
the university board, I formed a translation group, inviting Professor Robert Hughes (the Faculty of Regional Development Studies) as a translation rewriter, Professor Nicholas Lambert (the Faculty of Human Life Design) for proofreading, and Professor Miura for references.

In these days of globalization, there is a need to explain Toyo University to those outside of Japan. Many international students and visiting researchers from other countries have been coming to Toyo University; therefore, the university should define what kind of university it is and what learning is offered. Hopefully, for readers, this book can convey the spirit and history of Toyo University as well as the general history of higher education development in Japan since the Meiji era. It is my desire that many people read this book and come to know how Toyo University was established through the educational motto of its founder Dr. Enryo Inoue: The basis of all learning lies in philosophy. This is a very unique principle in the history of education in Japan.

The book jacket was designed by Mr. Seiji Kanie, who already designed the cover of the Japanese version. Lastly, I want to express my sincere gratitude to him and the other Toyo staff involved in the publication of this English version. 